Winter 2005

\title{
Programs for Democratic Citizenship in Mexico's Ministry of Education: Local Appropriations of Global Cultural Flows
}

Bradley A. U. Levinson

Indiana University

Follow this and additional works at: https://www.repository.law.indiana.edu/ijgls

Part of the Comparative and Foreign Law Commons, Education Law Commons, and the International Law Commons

\section{Recommended Citation}

Levinson, Bradley A. U. (2005) "Programs for Democratic Citizenship in Mexico's Ministry of Education: Local Appropriations of Global Cultural Flows," Indiana Journal of Global Legal Studies: Vol. 12 : Iss. 1 , Article 9.

Available at: https://www.repository.law.indiana.edu/ijgls/vol12/iss1/9

This Symposium is brought to you for free and open access by the Law School Journals at Digital Repository @ Maurer Law. It has been accepted for inclusion in Indiana Journal of Global Legal Studies by an authorized editor of Digital Repository @ Maurer Law. For more information, please contact rvaughan@indiana.edu.

\section{$\Psi$}

JEROME HALL LAW LIBRARY

INDIANA UNIVERSITY

Maurer School of Law
Bloomington 


\title{
Programs for Democratic Citizenship in Mexico's Ministry of Education: Local Appropriations of Global Cultural Flows
}

\author{
Bradley A.U. Levinson *
}

\section{INTRODUCTION}

Recent scholarship in comparative education has called attention to the problems and challenges associated with the intensified globalization of educational programs. ${ }^{1}$ Structural arrangements for schooling in poorer countries have become increasingly subject to the mandates of neoliberal economic policy as these are dictated by powerful international agencies and national elites. In places like Latin America, the recent predominance of schemes for educational decentralization, privatization, and "accountability" illustrate that, in matters of policy, the sovereign state is indeed strongly "conditioned" by external influences. ${ }^{2}$

However, as Arnove and Torres emphasize, globalization processes always entail a "dialectic of the global and the local," in which the outcome is never foreordained. ${ }^{3}$ If structural reforms tend to show the heavy hand of the global market at work, thus favoring the global over the local, then on questions of curricular content, teacher education, textbook production, and the like, the effects of neoliberal globalization are much less clear. Developments in curriculum and pedagogy more explicitly engage the terrain of ideologies and cultural values, and are arguably less malleable to external conditioning or subject to external oversight. Moreover, social actors rooted in local cultural traditions are more likely and able to appropriate such prescribed changes and transform

*Associate Professor, Indiana University-Bloomington. B.A., 1984, University of California - Santa Cruz; M.A., 1989, Ph.D., 1993, University of North Carolina.

1. See Comparative Education: The Dialectic of the Local and the Global (Robert Arnove \& Carlos Alberto Torres eds., 2d ed. 2003) [hereinafter Comparative Education]; Globalization and Education: Critical Perspectives (Nicholas C. Burbules \& Carlos Alberto Torres eds., 2000); Globalization and Education: Integration and Contestation Across Cultures (Nelly P. Stromquist \& Karen Monkman eds., 2000).

2. See Robert F. Arnove et al., A Political Sociology of Education and Development in Latin America: The Conditioned State, Neoliberalism, and Educational Policy, 37 INT'L J. Comp. Soc. 140 (1996).

3. See Robert F. Arnove, Introduction: Reframing Comparative Education: The Dialectic of the Global and the Local, in Comparative Education, supra note 1, at 2-3. 
them into something rather different from what was originally intended. Thus, if so-called cultural globalization has only an indirect relationship to economic globalization, then certain aspects of cultural globalization, such as curriculum, may be even more subject to local transformations.

One of the most interesting and pertinent arenas for investigating the question of cultural globalization is in the emerging global network of organizations and government ministries dedicated to democratic civic, or citizenship, education. Over the last twenty years, new forms of democratic governance have been developed in nations that had previously experienced a long period of authoritarian or totalitarian rule. Not surprisingly, countries with little or long-submerged democratic experience at the national level have been most active in revising programs for civic education in order to create a broad-based democratic political culture to accompany structural reforms. ${ }^{4}$ Perennially a bulwark of national identity and allegiance for more authoritarian regimes, schools are now seen as the potential seedbeds for a new kind of democratic citizen. ${ }^{5}$ To be sure, "newly democratizing" countries have occasionally undertaken to survey and revive more local democratic traditions and practices within their own borders. ${ }^{6}$ Yet in articulating the form that education for democratic citizenship should take, such countries have more often than not reached out to other countries and international organizations. An ever-growing array of liberal democratic governments and related nongovernmental organizations stand ready to meet their needs. ${ }^{7}$

4. See generally Democratizing Education and Educating Democratic Citizens: International and Historical Perspectives (Leslie Limage ed., 2002) (discussing the school systems in various democratic countries) [hereinafter Democratizing Education]; Diversity and Citizenship Education: Global Perspectives (James A. Banks ed., 2004).

5. See generally Democratizing Education, supra note 4.

6. I insist on maintaining scare quotes around the phrase "newly democratizing" because of the ideological assumptions it entails. Along with another common phrase, "transition to democracy," such characterizations of national regimes betray a modernist legacy that assumes a kind of progressive evolution from authoritarianism to democracy. In this reigning conception, the United States and other "advanced democracies" gift their knowledge and understanding to nations that have never experienced full political democracy. Yet such a view fails to acknowledge the existence of other democratic projects and traditions in the long histories of the countries and regions now shifting to formal, representative democracy. See Julia Paley, Marketing Democracy: Power and Social Movements in Post-Dictatorship Chile (2001); Frederic C. Schaffer, Democracy in Translation: Understanding Politics in an Unfamiliar Culture (1998).

7. See Bradley A.U. Levinson \& Margaret Sutton, Doing the Ethnography of Democratic Citizenship Education: The Global Meets the Local in Mexico and Indonesia, Paper presented at the American Anthropological Association, Chicago, 11l. (Nov. 19, 2003). See generally Democratizing Education, supra note 4. 
A long tradition of thought about the bases for political citizenship takes as its model of democracy the constitutionalist liberal democracies of the North. ${ }^{8}$ Citizens in the modern nation-state are defined as those with constitutionallyspecified rights and obligations, which typically include voting, due process, free speech, respect for law, defense of the country, and so forth. This model of citizenship is centrally functional to the operation of the nominally democratic nation-state, which has in the past fifty years become the hegemonic, if not universally recognized, global mode of governance. In this political framework, "responsible citizenship in a constitutional representative democracy" requires "the capacity for informed, reasonable, deliberative and freely made choices in response to competitive public elections and contested public policy issues." And in virtually every nation-state, of course, mass public education is charged with substantially forming the citizen. ${ }^{10}$

One of the fundamental presuppositions of this paper is that the model political citizen of constitutionalist democracy, legitimated by Western political theory and exported now around the world, actually enfolds a number of partic-

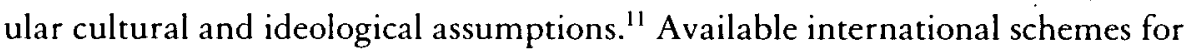
democratic citizenship thus tend to place emphasis on representative government and certain forms of civic "engagement" or "participation." In terms that may be more or less explicit, such schemes articulate a cultural model of the "educated person," an idealized set of attitudes, skills, and knowledge. ${ }^{2}$

Mean while, particular nations and their diverse cultural configurations may advance other models of the educated person-differing conceptions of democratic governance, differing conceptions of civic engagement, and differing models of citizenship which may encompass both democratic and nondemocratic elements. When globally hegemonic models of political citizenship and

8. See Citizenship in Diverse Societies (Will Kynilicka \& Wayne Norman eds., 2000).

9. John J. Patrick, Presentation at the Conference on Education in Democracy for Social Studies Teachers: An Institute for Teacher Educators (May 17, 2002).

10. John Boli, New Citizens for a New Society 49 (1989); George M. Thomas et al., Institutional Structure: Constituting State, Society and the Individual 196 (1987).

11. Among other presumed attributes of the model political citizen is the capacity, even propensity, for making "rational choices" in highly individualistic fashion. For a critique of these assumptions, see Mary Douglas \& Steven Ney, Missing Persons: A Critique of the Social. Sciences 120-122 (2001).

12. See Bradley A. Levinson et al., The Cultural Production of the Educated Person: Critical Ethnographies of Schooling and Local Practice 21-23 (1996) [hereinafter The Cultural Production]. 
cultural personhood meet the embedded cultural definitions of citizenship present in the manifold spaces of "newly democratizing" countries, unique appropriations are likely to take place. As a number of case studies have illustrated, the expansion of Western institutional forms, such as modern schooling, does not so much impose a new regime of meanings as provide a new template for both making and insinuating existing meaning. ${ }^{13}$ Thus, the emerging forms of education for democratic citizenship can be seen as complex amalgams of both native and externally appropriated ideas of democracy and citizenship. ${ }^{14}$

In this paper, I sharply focus my analysis on recent efforts to create and implement programs for democratic citizenship education at the secondary level in Mexico. Drawing on numerous interviews with key Mexican education policymakers and bureaucrats, as well as extensive document analysis and observational field notes, I tell the story of how an ambitious national program for democratic civic education took shape within the Mexican National Ministry of Education over the course of the 1990s. This program, designed for early adolescents, was informed by myriad authors and ideas, many of them extra-national,

13. See Carolyn Bledsoe, The Cultural Transformation of Western Education in Sierra Leone, in Schooling the Symbolic Animal: Social and Cultural Dimensions of Education 138-40 (Bradley A.U. Levinson ed., 2000); Juliana Flinn, Diplomas and Thatch Houses: Asserting Tradition in a Changing Micronesia 97-138 (1992). See generally Local Meanings and Global Schooling: Anthropology and World Culture Theory (Kathryn Anderson-Levitt ed., 2003).

14. The concept of "appropriation" that I employ here has been developed as part of a broader project conceptualizing policy as a form of social practice. See Policy as Practice: Toward a Comparative Sociocultrual Analysis of Educational Policy (Margaret Sutton \& Bradley A.U. Levinson eds., 2001) [hereinafter Policy as Practice]. This project draws on various authors and theoretical traditions, including the Marxist phenomenology of Agnes Heller. See Agnes Heller, Everyday Life (1984). Agnes Heller was interpreted by Mexican anthropologist Elsie Rockwell and her associates. See Elsie Rockwell, Keys to Appropriation: Rural Schooling in Mexico, in The Cultural Production, supra note 12, at 301-03; Elsie Rock well, Desde la Perspectiva Del Trabajo Docente (1987). The project also calls on cultural studies of the media such as those described by Jan Nespor and Richard Johnson. See Jan Nespor, Tangled UP in School: Politics, Space, Bodies, and Signs in the Educational Process, at xiii (1997); Richard Johnson, What Is Cultural Studies Anyway?, 16 Soc. Text 72 (1987). Qualitative sociology work also is included in my project. See William A. Corsaro, Interpretive Reproduction in Children's Peer Cultures, 55 Soc. Psych. Q. 160 (1992). Scholarship in legal anthropology is also included. See Rosemary J. Coombe, The Cultural Life of Intellectual Properties: Authorship, Appropriation, and the Law (1998). Across these various traditions, appropriation refers to an active process of cultural production in which a social group borrows, recontextualizes, reshapes, and resignifies existing cultural forms and artifacts. In short, appropriation refers to the process of taking something and making it "one's own." 
but it was essentially a Mexican product. One important dimension of local appropriation, then, occurred through the manner in which heterogeneous global conceptual elements became inserted and blended in the Ministry of Education's work. I then shift to briefly examine a more recent program for citizenship education, also for the secondary level, brought to Mexico shortly after 2000. This program, developed by a U.S. professor of government and implemented in places like Sicily and Hong Kong, was imported with few substantive modifications. Whatever local appropriation occurs here, then, would have to be analyzed at the level of program implementation-the teaching and learning of the program in schools.

By examining how programs and policy formation for democratic civic education have unfolded in Mexico over the last ten years, I hope to illustrate the unique and unexpected ways that one instance of the state-the Ministry of Education-goes about attempting to educate democratic citizens. I attempt to theorize important continuities and disjunctures across these different approaches to democratic civic education, and to thereby situate the local appropriation of global flows of ideas about democracy and citizenship. A key question for this paper is how democracy becomes "glocalized" in and through particular educational programs for democratic citizenship. ${ }^{15}$

\section{The Secundaria, Civic Education, and the Creation of the Program in "Civic and Ethical Formation"}

\section{A. Political Conjunctures and the Vicissitudes of Civic Education in Mexico}

The 1917 Mexican Constitution, forged during the years of the revolution against the dictatorship of Porfirio Díaz, is an updated version of the original Liberal Constitution of $1857 .{ }^{16}$ It remains the law in Mexico. Although the Constitution provides for a progressive federal republic, with a separation of executive, judicial, and legislative powers, a bicameral congress, and considerable state and municipal autonomy, ${ }^{17}$ the reality in post-Revolutionary Mexico has been distinct.

15. See Heidi Ross \& Jingjing Lou, "Glocalizing" Chinese Higher Education: Groping for Stones to Cross the River, 摸着石头过河, IND. J. Global Legal Stud., Winter 2005, at 227.

16. Daniel C. Levy \& Kathleen Bruhn, Mexico: The Struggle for Democratic DevelopMENT 45-46 (2001).

17. Id. at 46. 
Deeply rooted in the habits of colonial and dictatorial rule, Mexico quickly turned into what many have called a presidentialist regime. ${ }^{18}$ The concentration of power in the president's office led to a subordinate judiciary and a rubber-stamp legislature. ${ }^{19}$ By 1929 , the President had formed the political party that eventually came to be known as the Institutional Revolutionary Party (Partido Revolucionario Institucional, or PRI). Drawing together different sectors of society (skilled labor, the peasantry, business groups, etc.), the PRI developed a disciplined corporatist machine that helped identify the party with the state and perpetuate single-party rule. ${ }^{20}$ Importantly, the national teachers' union (SNTE) effectively came to serve as one of the bastions of PRI support. ${ }^{21}$ Although then a nominally democratic nation, for over seventy years the PRI ruled Mexico with an iron fist, using a combination of carrot and stick, and sometimes outright electoral fraud, to keep itself in power. ${ }^{22}$ In addition to holding a constant majority in the Congress and controlling all major ministry appointments, the PRI controlled most mayoralties and virtually all state governorships. ${ }^{23}$

It was not until the late 1970s that significant electoral reforms began to open the possibility for meaningful opposition politics in Mexico. The democratic student movements of the 1960s and early 1970s, repressed by the PRI, began to bear fruit as their former participants moved into decision-making positions. ${ }^{24}$ Then, the economic crisis of the 1980 s, followed by a series of neoliberal reforms, further reduced the legitimacy of the single-party state, which had long used the profits from oil sales to finance a populist agenda. ${ }^{25}$ Several important mayoralties and governorships fell to opposition parties in the 1980s, and in 1988 the PRI resorted to massive electoral fraud in order to reclaim the presidency from the renegade candidate Cuauhtémoc Cárdenas. ${ }^{26}$ The PRI attempted to recover legitimacy throughout the 1990 s by agreeing to further electoral reforms and conducting more transparent business, ${ }^{27}$ yet certain democratic gains were

18. See, e.g., Joe Foweraker et al., Governing Latin America 113 (2004).

19. Levy \& BruHN, supra note 16 , at 103, 105.

20. Id. at 68-86.

21. Maria Lorena Cook, Organizing Dissent: Unions, the State, and the Democratic Teachers' Movement in Mexico 64-65, 71, 76 (1996).

22. See Levy \& Bruhn, supra note 16, at 86-88.

23. See id.

24. Id. at 50,58 .

25. See id. at 165-66.

26. See id. at 89.

27. See id. 
irreversible. The economic crisis deepened, as did the presence of new democratic actors in civil society who were determined to force the peaceful resolution of social problems, through civil disobedience if necessary. Chief among these nongovernmental organizations were those devoted to human rights, women's rights, indigenous peoples, economic justice, and the environment. ${ }^{28}$

Throughout these changes, the national ministry of public education, called the Secretaría de Educación Pública, or simply SEP, has played an important role. An ideological child of the revolution, the SEP was created in 1921 to advance the integrative and developmentalist agenda of the nascent state. Modeled on both the French and the German systems, and highly centralized in Mexico City, the huge bureaucracy of the SEP controls most of the formal educational enterprise in Mexico. ${ }^{29}$ Through the control of teacher education, the hiring of all teachers, and the production of common textbooks for all of basic education, the SEP has historically been a key instrument of state formation and the creation of national identity. ${ }^{30}$ Important modernization reforms since 1993 have arguably curtailed the power of the SEP. For instance, administrative decentralization has put the states in charge of budgeting and teacher hiring; and since the declaration of "middle basic education," or secundaria (grades seven through nine, roughly ages twelve to fifteen), as part of the cycle of compulsory schooling, textbooks for this level are now produced outside the SEP. ${ }^{31}$ Still, matters of curriculum and educational planning, especially, are still highly concentrated in the SEP. ${ }^{32}$

The practice of civic education through secondary schooling in Mexico has a history that is roughly coterminous with the SEP itself. In 1928, a separate Office of Secondary Education was created, and at this time the secundaria became explicitly conceived as an institution serving the "adolescent" life stage. ${ }^{33}$ Moisés Sáenz, considered by most the founder of the secundaria, ${ }^{34}$ had studied at Co-

28. See Foweraker et al., supra note 18 , at 147-48.

29. See Bradley A.U. Levinson, We Are All Equal: Student Culture and Identity at a Mexican Secondary School 73, 365-66 nn.6-17 (2001).

30. See Gilbert M. Joseph \& Daniel Nugent, Everyday Forms of State Formation: Revolution and the Negotiation of Rule in Modern Mexico (1994); Carlos Ornelas, El Sistema Educativo Mexicano (1995).

31. Ornelas, supra note 30.

32. Id.

33. See Ernesto Meneses Morales, Tendencias Educativas Oficiales en Mexico, 1911-1934 (1986); Bradley A. Levinson, "Una Etapa Siempre Dificil": Concepts of Adolescence and Secondary Education in Mexico, 43 Comp. Educ. Rev. 129, 131 (1999).

34. Id. at 146. 
lumbia University with John Dewey. Yet, while the U.S. junior high school advocated by Dewey had been developed in part to foster individual identity formation and critical thinking, the Mexican secundaria emphasized the importance of curtailing selfish individualism and creating a sense of social solidarity. ${ }^{35}$ The goal of the secundaria was to balance the desire for a curriculum more specialized than the primaria - a curriculum that would offer students the chance to explore their vocational options-with the themes of integration and national unity. The goal, in other words, was to accommodate the "individual differences" of the students while still subordinating individual interests to the imperatives of "solidarity," "cooperation," and so-called "social values." 36

The presidency of Lázaro Cárdenas (1934 to 1940), the great populist reformer, oversaw a significant growth in secondary enrollments. Now with an avowedly socialist educational program, children of workers were more strongly encouraged to continue their schooling as the secundaria turned more "technical," and the curriculum included more hours devoted to practical, productive activities. It was at this time that "vocational counseling" (orientación) first appeared in the secundaria. Also at this time, the teaching of history and civics was given new emphasis. In 1932, the curriculum added a course in "civic culture" to the required courses of Spanish, foreign language, mathematics, science (biology, chemistry, and physics), geography, and history for each of the three years. This course added an important critical element to the curriculum, as it focused on political, economic, and legal "problems" in Mexico. By 1937, the course in civic culture had been changed to "socialist information and practice," and students increasingly learned about class conflict and imperialism as a way of understanding Mexican history. They participated in student government and mutual-aid societies to practice cooperative social work. Finally, students made frequent trips to shops and factories in order to gain a fuller appreciation of working-class life.

The short-lived socialist experiment ended abruptly in 1940, as the reins of presidential power swung over to the more conservative Avila Camacho. ${ }^{37}$ If the school under Cárdenas had given preference to workers and had become the school of struggle, under Avila Camacho's Secretary of Education, Véjar Vázquez, it would become the school of love, and under the next Secretary, Tor res

35. See id. at $138-140$.

36. See Morales, supra note 33, at 486.

37. See Levy \& Bruhn, supra note 16 , at 49. 
Bodet, the school of unity. Official educational discourse thus reinstated the single importance of "national unity" and reconciliation above class struggle. Civic education came to place more emphasis on national heroes and patriotic duty. ${ }^{38}$

The secundaria continued to expand under Avila Camacho. As the Mexican state entered into a period of more comfortable alliance with national and transnational capital, the official discourse of this period constructed the interests of the nation, of subordinated classes, and of capital as convergent; each could win in the formula for national development, modernization, and the stabilization of a "revolutionary" regime. ${ }^{39}$ This formula then provided the basic continuity in policy and practice around the secundaria at least until 1974, perhaps even until 1992. In the period from 1950 to 1970 , there was a 1,000 percent increase in secundaria enrollments, mainly due to the growing participation of female students, who came to form half the student body in most secundarias by the late $1970 \mathrm{~s}^{40}$

Before 1974, then, civic education had always been present in the secundaria, though it was oriented more toward unity and solidarity (of class, of nation) than to the construction of a democratic citizen. In 1974, there was another significant modification of the secundaria curriculum. Among other things, the so-called Chetumal Reforms brought together previously separate subjects (asignaturas) into multidisciplinary fields of inquiry, called áreas. ${ }^{41}$ Thus, for instance, biology, chemistry, and physics came together as "natural sciences," and were given a combined seven hours per week in the national curriculum. ${ }^{42}$ For our interests here, history, geography, and civics were combined into "social sciences," and also given seven hours of the weekly study program. ${ }^{43}$ Teachers who had previously been more strongly specialized in, and identified with, one of three subjects, now had to cover a broader field of social sciences. The teaching of civics was folded into the new social science curriculum, and not always in a wholly coherent fashion. ${ }^{44}$

38. Ernesto Meneses Morales, Tendencias Educativas Oficiales en Mexico, 1934-1964 (1986).

39. See Nora Hamilton, The Limits of State Autonomy: Post-Revolutionary Mexico 26770 (1982).

40. David Barkin, Education and Class Structure: The Dynamics of Social Control in Mexico, Politics and Society 2, 5 (1975).

41. Ornelas, supra note 30.

42. Id.

43. Id.

44. Although the Chetumal Reforms were adopted widely throughout the country, they were not legally required of all schools. Therefore, throughout the remainder of the $1970 \mathrm{~s}$ and $1980 \mathrm{~s}$ a number of localities, most notoriously Mexico City, continued to operate according to the older asignaturas. This created in effect a dual national system of secundaria curriculum. 
From 1992 to 1993, a series of educational "modernization" measures included an important amendment to the constitutional article mandating public education and a new "general law" of education. ${ }^{45}$ The amendment now made secundaria attendance compulsory, thereby raising the stakes of civic education at that level; the new law also stipulated values of critical reflection, democratic participation, and human rights. From 1993 to 1999, the older asignaturas returned to all secundarias in Mexico, with civics accorded just three hours between the first and second years. A brand new subject, Educational Orientation (Orientación Educativa), was added to the third year of studies, along with a three-hour elective course that the states and localities could determine according to their own needs and interests. ${ }^{46}$ It was during this time that many social workers, psychologists, and "vocational counselors" made their first regular appearances in classrooms. Previously, such school personnel had been limited to occasional classroom visits to conduct vocational aptitude tests or to lead discussions about sexual development. After 1993, however, many of these personnel became regular classroom instructors, charged with teaching a new subject that combined vocational orientation with elements of self-exploration, sex education, and drug and crime prevention.

\section{B. Influences and Institutional Dynamics in the Creation of the FCE}

The next serious reform of Mexican civic education, which most concerns us here, began in the mid-1990s. During the last PRI presidential administration (1994 to 2000), the Secretary of Education gave a team the charge to create an ambitious new program for all three years of middle basic education (secundaria). The program eventually came to be known as "civic and ethical formation" (FCE). ${ }^{47}$ The policy process for the reform of civic education in Mexico

45. Ornelas, supra note 30.

46. Secretaría de Educación Pública, Formación Cívica y Etica: Programas de Estudio Comentados (2000) [hereinafter Programas de Estudio Comentados].

47. In the Mexican lexicon, educación has always had a broader meaning than mere instrucción, and formación indicates a fuller approach than educación. While instruction, and even education, can refer to the transmission and acquisition of facts and knowledge through mental processes, formation points to habit and affect, with the intention of shaping forms of perception and conduct in everyday life. The Mexican secundaria has always presumed to be formativo and integral (holistic), thus the new FCE program does not so much propose a new focus as recover and reinforce one of the secundaria's perennial goals. 
received a strong impulse, according to many, from then-President Ernesto Zedillo (1994 to 2000), who had actually served as Secretary of Education for a few years during the prior presidential administration, between 1988 and 1994. Zedillo had been the primary architect of the modernization reforms of 1992 and 1993, which among other things enshrined new language in the federal education law that made participatory and "pertinent" education a cornerstone of national development. ${ }^{48}$ Such emphases were reiterated in the national Program for Educational Development (1995 to 2000) under Zedillo's presidency, which highlighted the goals of achieving educational "equity, quality, and relevance" (pertinencia). ${ }^{49}$

There is good evidence that Ernesto Zedillo was reading and channeling a variety of social concerns that had been brewing for over a decade. Based on my previous fieldwork, my reading of popular and scholarly literatures, and my ongoing trips to Mexico, I have identified at least three powerful societal discourses that formed and expanded throughout the 1980s and 1990s. Each one of these discourses expressed certain understandings of democracy, and each one, I argue, impacted the eventual formation of the new program for citizenship education. Such discourses emerged out of rather different social sectors and movements, but each one articulated a set of existential concerns that cut across broad sectors of Mexican society. Each one also highlighted a different set of "values" that needed to be recovered or constructed. Finally, if there is one theme that cuts across all the discourses, it is the concern with human rights and the creation of a culture of "tolerance." Fed up with political violence and economic misery, and disgusted by the impunity accorded to most perpetrators, many Mexicans by the 1990s had seized upon human rights as a crucial value. The notion of human rights, in turn, was often vitally linked to the attainment of democracy. However, human rights could also become a kind of Rorschach of cultural projection: the place of human rights, and the route to achieving a regime respectful of such rights, would vary by discourse and social sector.

One discourse, which I call "lost values" (valores perdidos), drew attention to the signs of what many observers call "social disintegration," such as increased violence, corruption, divorce, and disregard for adult authority. The assumption made by this discourse was that traditional values of respect, honesty, and obedience had once effectively ordered society, but had since fallen into disuse. There was a strong sense of proper social hierarchy having become challenged and

48. Programas de Estudio Comentados, supra note 46.

49. Id. 
turned upside-down. Most strongly articulated through conservative Catholic organizations such as the national "Parents' Union" (UNPF), the discourse on lost values nevertheless resonated with a much broader public. The often explicit solution proposed by the very same discourse was the recovery of values that had been "lost" in recent years-typically through religious education or other kinds of catechistic instruction, and the reassertion of paternal control.

Another discourse, which I call the active and "critical citizen" (el ciudadano crítico), highlighted the importance of creating deeper democratic habits and a political culture that would support a democratic transition over the longer term. Most strongly articulated by a generation of left-leaning Mexican intellectuals and leaders who had come of age in the political opposition to the PRIdominated state, the discourse of the "critical citizen" called for a new participatory sensibility amongst citizens, most of whom were seen as having grown complacent, fatalistic, or too accustomed to state largesse. This form of participation presupposed an ethos of respectful dialogue but also critical questioning, in which existing social hierarchies and received norms would be subject to constant critique. The new citizen would actively consider different social and political options through a critical discursive process, and arrive at independent stances. The discourse of the critical citizen implicitly valued equality over hierarchy-gender equity was often prominently touted as a goal. Although it originated in the more highly schooled sectors of society, this discourse, too, found resonance across broad sectors of society that had been irrevocably changed by experiences of immigration and/or consumption of cultural media such as television, movies, popular music, and the Internet. ${ }^{50}$

The third discourse, which I call "accountability" (rendición de cuentas), virtually created a new phrase in Mexican Spanish overnight, since there had been no adequate predecessor to this cultural import. Even more clearly influenced from abroad than the others, the discourse on accountability called for greater transparency in public management and more valid and neutral forms of evaluation in assessing educational "quality." One of the important assumptions of this discourse was that the goals of transparency and quality called for both institutional and personal transformations. On the one hand, new kinds of institutional arrangements, such as the creation of a quasi-independent National Institute for Educational Evaluation (INEE), or the implementation of a merit-

50. Cf. Levinson, supra note 29, at 159-63 (discussing how media sources give Mexican secondary school students local and global perspective of their society). 
based assessment of teacher performance, would leverage higher quality and greater public accountability. On the other hand, the discourse called for the cultivation of a new subjectivity which placed responsibility for public outcomessuch as students' learning-on individuals as well as institutions. In this sense, the new democratic citizen had to learn to become more responsible-that is, accountable-for his or her actions.

The growth of these societal discourses clearly put the need for some kind of citizenship education on the national agenda. Time and time again, people who were involved in some way with the creation of the FCE program alluded to aspects of these societal discourses and the social pressures that accompanied them. Usually, the pressures were characterized in rather general terms, with reference to "values" above all. ${ }^{51}$ As the main author of the FCE program put it, for instance, "There was an urgent social demand, expressed in many different venues, that values be taught, that there was a lack of values [in the current generation]. ${ }^{152}$ Such social pressures, of course, would have to be channeled and mediated in specific ways through the bureaucracy of the SEP, which is relatively impervious to the demands of particular social movements. Indeed, as I highlight here, the final impetus for development of a program like FCE would come from the personal initiative of key actors-the President, the Secretary of Education, and perhaps most decisively and remarkably, the Secretary's wife.

The Secretary of Education who took over shortly after the beginning of the Zedillo administration, Miguel Limón, is a professor of constitutional law with a long trajectory of civil service. After having served as Dean of Social Sciences at the Autonomous Metropolitan University in Mexico City and Academic Secretary at the National Pedagogical University, Limón went on to serve for a number of years as director of the National Institute for Indigenous Affairs (INI), as Subsecretary of the Interior (Gobernación) for Migration and Population, and finally as Attorney General for Environmental Protection..$^{53}$ This list of positions covers a remarkable range of issues and concerns that were eventually encompassed by the FCE program; indeed, the former Secretary himself pointed out that each of these former positions had a strong "ethical" dimension

51. See Pablo Latapi Sarre, El. Debate Sobre los Valores en la Escuela Mexicana (2003).

52. Interview with main author of the FCE program, in Mexico City (2001) (on file with author).

53. Interview with Miguel Limón, former Secretary of Education, Mexico, in Mexico City (Aug. 2003) [hereinafter Interview with Miguel Limón] (on file with author). Interviews were conducted in Spanish and the translations included in this article are mine. 
(contenido ético), and that he saw his appointment as Secretary as a grand opportunity to bring this ethical dimension to public education. ${ }^{54}$ Yet why did Secretary Limón give the development of citizenship education such a high priority among the many pressing educational problems confronting him at the outset of his administration? On this point, the former Secretary revealed the influence of his wife. When I asked him to reflect on how his biography influenced his interest in the FCE program, he started in with a chuckle:

Look, in the first place let me tell you something: I'm married to a teacher, an educator, and she has had a lot of influence on my education as an adult... She has been very important in all of this, she really insisted and persevered with me so I wouldn't lose sight [of civic and ethical education] beyond all the fog that is created as part of bureaucratic routine. Her insistence was in that sense very, very important. 55

The Secretary then went on to describe how his wife eventually formed the crucial authorship team for FCE. She became a member of the team and an active contributor to the development of the program.

For her part, the Secretary's wife, the Maestra Campillo, placed the highest emphasis on the multiplicity of perspectives and materials that shaped the program. As she traveled with her husband to numerous international meetings during the early part of his tenure, she took advantage of each site to gather materials on civic education. Among the sites she mentioned most prominently were Switzerland (for UNESCO), France (where her husband had studied many years before), Spain, England, the United States, various countries of South America, and perhaps most intriguingly, Japan. As she put it in response to my question about whether foreign influences had shaped FCE:

I had the advantage that my husband was speaking regularly with the ministers, the policymakers, so the obligatory question on my part was always, 'Please, ask them what they're doing in this area [of civic education].' ... There's no influence from a single place

54. Id.

55. Id. 
but we are certainly, and necessarily, influenced by the materials that we have read. ${ }^{56}$

Maestra Campillo went on to describe the involvement of prominent curriculum experts in civic education from Spain and Argentina, who were invited at different times to share their experiences and review the emerging Mexican program. She also called attention to her own studies of Japanese, and her sons' enrollment in a private Japanese school in Mexico City. All of these contacts served to provide models and ideas which the team would appropriate into its design of the FCE.

One other measure of global cultural influence can also be inferred from patterns of citation and reference in program documents and supporting literature. In support of ideas about participatory democracy and student-centered pedagogy, one finds frequent reference to John Dewey, Michael Apple, ${ }^{57}$ and others in the U.S. critical tradition. Yet even more frequently, one finds substantive citations of Spanish, French, and Italian educators, philosophers, and political theorists. The affinity for Spain is perhaps obvious because of the common language, yet also because of the long struggle against military dictatorship that formed the Spanish twentieth century. The celebrated Spanish philosopher Fernando Savater is often cited, as is the Spanish curriculum theorist Gimeno Sacristán. In the case of France and Italy, it is not uncommon to find support for certain conceptions of democratic citizenship in the writings of well-known social and political theorists like Alain Touraine, Norberto Bobbio, or Giovanni Sartori. ${ }^{58}$

Meanwhile, in the course of her travels, increasingly Maestra Campillo was called upon to share the outline of the FCE program that was taking shape. Almost without exception, the policymakers and educators with whom she shared the program displayed curiosity, even amazement, at how such a program could be extended to cover all adolescents in a country the size of Mexico. Thus, Maestra Campillo suggests, there was as much give as take, and by the time the program was nearing completion, in early 1999 , they were receiving many requests to share their own ideas about how to conduct democratic citizenship education for adolescents.

56. Interview with Maestra Campillo, wife of Miguel Limón, former Secretary of Education, Mexico, in Mexico City (Oct. 2001).

57. Micael Apple is a world-renowned critical theorist of education policy and curriculum. See, e.g., Michael Apple, Education and Power (1982).

58. Secretaría de Educación Pública, Formación Cívica y Etica, Educación Secundaria: Libro Para el Maestro (2001) [hereinafter Libro Para el Maestro]. 
Societal discourses, as I have discussed, created impetus and formed an important backdrop for the work of the FCE team. They provided a critical "problem diagnosis" for policy reform. ${ }^{59}$ Public concerns about values were often expressed through the media, or directly to the President's office, and then channeled to Limón. Such discourses also established a set of implicit parameters within which the FCE team would have to conduct its work. Still, the personal goals of the Secretary and the Secretary's wife, and the international experiences of the FCE team members, were more proximately determining of the way that global ideas of democratic citizenship were appropriated in the creation of the FCE. Here, I rejoin the narrative about the birth of the FCE program.

Legitimated by public discourse, supported by the President, and bolstered by the general goals of the Plan for Educational Development 1995-2000, by 1995 Limón felt a clear mandate to begin the reform of civic education to include a stronger component of "values formation" as well as participatory pedagogy. ${ }^{60}$ Ordinarily, proposals for curricular reform within the SEP would have been routed through the appropriate content "team" in the General Directorate of Educational Methods and Materials, under the Subsecretary of Basic Education. ${ }^{61}$ The Secretary, in consultation with the President, would provide a policy mandate to reform curriculum, and would instruct the Subsecretary to put the reform into motion through the appropriate content team. However, Secretary Limón proceeded differently. First, he convened a prominent group of educational researchers to produce a white paper on the topic of citizenship and values education. This group was coordinated by one of the foremost education scholars in modern Mexican history, a man whose principled and pointed criticism had often caused problems for previous PRI administrations. When the white paper was delivered, the discussion about how to create a program in civic education was really just beginning. The Subsecretary for Basic Education, Olac Fuentes, took a less active role in these discussions. In his mind, there were more pressing matters requiring resources and attention, and he also worried about giving teachers too much latitude to teach civic "values." ${ }^{2}$ This is apparently why Secretary Limón took the unprecedented step of convening a separate team

59. See Policy as Practice, supra note 14.

60. Interview with Miguel Limón, supra note 53.

61. Id.

62. Interview with Olac Fuentes, former Subsecretary for Basic Education, Mexico, in Mexico City (Oct. 2001). 
of advisors to draft the new program in civic education. The team was literally housed in Limón's private offices and figuratively taken under his wing. His wife would come to form the symbolic heart of the team, and a female Harvardtrained educational philosopher was selected to head it up. Then two more male members were added-one a classical musician and music professor of broad reputation, the other a writer of fiction and social commentary.

This team took the draft white paper produced by the specially convened research team and went about seeking additional input from a variety of organizations and government agencies that had rarely been consulted in the past. Clearly, this was going to be a new, more collaborative process for curriculum and program design. Technical curriculum teams from all the states of the Mexican republic were invited to participate in early discussions, comment on drafts, and propose their own ideas. Among the organizations external to the SEP invited to submit proposals for content, and to vet the early drafts of the program, were the Catholic Church, the National Autonomous University of Mexico, the National Pedagogical University, the National Youth Institute, the Human Rights Commission of the Federal District, the Ministry of Health, and the Council on Addictions. Particularly important was a burgeoning collaboration with the Federal Electoral Institute (IFE), which had its own parallel program in citizenship education for a democratic political culture. ${ }^{63}$ For a period of nearly two years, there were numerous discussions and numerous drafts of the curriculum. All those involved characterized this time as one of intensive study and intensive discussion.

In the end, the four-member FCE team delivered a comprehensive threeyear program for the consideration of the civic education team in the General Directorate of Educational Methods and Materials—-the team that would have ordinarily been charged to produce the program itself. It had been made clear to

63. The IFE is a government-funded yet independent agency created in the late 1980 s mainly to administer fair and clean elections. However, a significant part of its work also includes fomenting civic education and the creation of a new democratic political culture. Through its Department of Electoral Certification, Civic Education, and Citizenship Participation, the IFE has run several educational programs that complement the school-based FCE curriculum. These include the Jornadas Cívicas Infantiles y Juveniles, day-long programs of activity that range from mock elections to drawing and role-playing; "Project-Citizen," a program adapted from the U.S.-based Center for Civic Education that fosters community involvement and problem solving among adolescents; and the elementary program, "Rights and Values for Mexican Children." Sylvia Salazar Ugarte, El IFE Ante la Educacion Cívica, 7 Educación (2001). 
this team, with all due discretion, that their expert input would be valued, but that all final decisions belonged to the FCE authoring team and Secretary Limón, for whom they directly worked. ${ }^{64}$ The civic education team was in accord with the basic orientation of the program and its pedagogical focus. Their greatest concern was with the overabundance and sequencing of themes; they made some observations that were heeded, and others that were not. In any case, the final product was judged sufficiently cogent and viable for the Subsecretary of Basic Education, Olac Fuentes, to give it his full support. Despite his earlier reservations, Fuentes provided the full support of his office to launch the new program, and he even proved an articulate defender of its core principles. ${ }^{65}$

\section{FCE Themes and the Influence of Societal Discourses}

An analysis of two key documents-the Annotated Program of Studies, and the Teachers' Guide ${ }^{66}$ - provides us with the major organizing themes and principles of the FCE. Throughout the text, the authors of these documents place emphasis on a communicative pedagogical stance, and a new role for the teacher as facilitator rather than provider of information. Such communication is intimately linked to the urgent need for students to take control of their learning and to begin practicing democratic virtues:

[The program] seeks to strengthen the student's capacity for critical analysis, for group work and participation in both individual and collective decision-making processes based on the values of a democratic life (translated by author). ${ }^{67}$

It will be necessary to create a learning community, understood as a space of dialogue and joint construction between teachers and

64. Interview with the Head of Civic Education Team of the General Directorate (Sept. 2001) (on file with author).

65. When it was finally published in February of 1999, the new FCE program also raised the hackles of the scholar whose team had drafted the original white paper. Many of his suggestions, it turns out, had been ignored or overruled. Among other things, he worried that the constructivist pedagogy relegated ethics to personal choice and left no room for establishing common grounds for moral action. See SARRE, supra note 51, at 198-202.

66. Programas de Estudio Comentados, supra note 46; Libro Para el Maestro, supra note 58.

67. Programas de Estudio Comentados, supra note 46, at 14. 
students, in which knowledge is sustained by information, experience, and reflection. The students will learn equally from their classmates and their teachers, manifesting in this way the importance of a dialogical and horizontal educational process (translated by author). ${ }^{68}$

The documents go on to criticize the heavy emphasis on information in the previous curriculum, saying, for instance, that:

in [the old civics] the contents were dominated by detailed description of our public institutions and the recital of human rights, to the detriment of a more systematic development of abilities and attitudes that might lead to greater civic participation. Even though important concepts and information were presented, because they showed no clear relation to their lives such concepts could not be easily experienced by the students as a priority in their education. In the new subject (FCE), we seek to make the connections between civics and students' lives more apparent (translated by author). ${ }^{69}$

Correspondingly, the new plan establishes a number of "pedagogical and didactic guidelines" for teachers. Such guidelines include, among other things, clear directions to:

- relate themes to students' lives

- foment... attitudes of respect and acceptance that encourage freedom of expression for all, taking special care to promote gender equity

- practice abilities of communication, dialogue, expression, and critical judgment

- encourage the practice of values, attitudes, and habits related to democratic life, to group work, and collective organization. ${ }^{70}$

68. Id. at 21-22.

69. Libros Para el Maestro, supra note 58, at 3.

70. $I d$. 
Clearly, these new guidelines create a significant break with the older, teacher-centered approach to civics instruction. Responding to the call for a more "relevant" education, they also clearly share key postulates with the societal discourse on the "critical citizen."

While civics has a long and illustrious history in Mexican schools, the term "ethical" is less familiar to most Mexicans. It also raises more eyebrows. This is because of its possible connection to specific moral values derived from the dominant religion of Catholicism. Steeped in the tradition of "lay" education (the separation of church and state), schoolteachers are especially vigilant about the introduction of religion to the public classroom. ${ }^{71}$ However, a close analysis of the new FCE program reveals strict adherence to a secular conception of ethical values-one that allows, but does not promote, the adoption of specific moralities. Indeed, my interviews with Secretary Limón and others involved with the FCE confirmed that one of their greatest concerns was to avoid the impression of endorsing a specific religious or political doctrine. Only in this way could they avoid controversy and appeal to a greater variety of societal discourses.

What exactly is the difference between "civic" and "ethical" education, and how do they mesh? The Teachers' Guide explains it this way:

Formación civica can be defined as a process of personal development through which individuals articulate values and form conceptions...that lead them to conceive of themselves as members of a political and social community, and to thereby exercise...the qualities of citizenship that the Constitution grants them ....

Formación ética can be defined as a process of human development in which the individual acquires and forms a set of abilities, attitudes, values, and knowledge that enables her to know herself and to recognize others as equal in dignity and rights.... (translated by author $)^{72}$

Each of these formative goals, in turn, is linked to the overarching concept and goal of democracy. The Guide seems to say that civic education can make

71. See Ornelas, supra note 30.

72. Libros Para el. Maestro, supra note 58, at 9. 
students aware of their rights and responsibilities as democratic citizens, but only ethical education can deepen the attitudes that make respectful participation possible. Importantly, the "individual" and his "personal development" are placed at the heart of civic education, but it is a development oriented toward "political and social community" and the "recognition of others."

The three years of secundaria study have been organized around three main themes that run throughout the FCE program. The first theme, focused on ethics, consists of "reflection about human nature and human values." 73 The first year course of study opens with a broad exploration; students consider the evolution of culture and the characteristics of homo sapiens as a species. Before long, the course centers on the perennial issue of gender relations and has students discussing what it means to "be a woman and be a man." This is just one of many points where gender becomes salient. ${ }^{74}$

The second theme, unusually reflexive with regard to their life stage, considers both "problems and possibilities for adolescents and youth."75 A major section of the first year, called "youth and goals" (juventud y proyectos), opens an explicit reflection about the promises of adolescence. Students are encouraged to project their aspirations into the future, to imagine their possibilities. There is a good deal of language here seemingly borrowed from humanistic psychology: "personal realization," "life cycle and life goals," and "human potential."76 There is also the first opening toward vocational orientation, as students are encouraged to "identify tastes, aspirations, and goals during the stage of adolescence." $"$ Finally, the first year ends with forty hours of instructional time spent exploring how to "live in society." Concepts include interdependence, communication, emotional connection (afectividad), enjoyment (gozo), solidarity, and reciprocity, as well as the "spirit of service, creativity, and work." Activities direct students to pose examples of such concepts in everyday life. ${ }^{78}$

The second year of the program picks up at the same point but gives a different twist to "living in society." Now, under the rubric of democracy, students learn about the "values of living together" (valores de la convivencia), as well as the more specific "civic values and citizenship formation." What are considered

73. Programas de Estudio Comentados, supra note 46.

74. Id. at 39.

75. Id.

76. Id.

77. Id. at 49.

78. Id. at 50. 
the key values of democracy are imparted to students: liberty, equality, equity, justice, respect, tolerance, solidarity, and responsibility. ${ }^{79}$

As if to give concrete and immediate meaning to these values, the second year moves on to consider students' relation to the secundaria itself. In an interesting example of institutional self-reflection, students are encouraged to explore their "reasons for attending the secundaria" and to ask themselves, "How do I take advantage of what the secundaria has to offer?" The goal here is to urge students to "acquire the elements for actively participating in society" by viewing the secundaria as a microcosm of the broader society. ${ }^{80}$ From the secundaria, teachers and students make the leap to the nation, exploring concepts such as "nationalism, love of country, and national pride," as well as "unity and cultural pluralism." in, and influencing, matters of national interest." ${ }^{82}$ Finally, the second year ends with a further opening out to the study of "humanity." It is here, for the first (and perhaps only) time, that students explicitly consider their "relationship to the environment." 83

The third and final theme centers on traditional civics concepts: "social organization, democracy, citizenship participation, and forms of government in Mexico"-in other words, the Constitution, the political structure (elections, parties), the governance structure (federal, state, and municipal agencies), and the separation of powers (executive, legislative, and judicial). Yet toward the middle of the year, the program of study returns to some themes that have already been introduced in previous years. These themes are considered under the rubric of "responsibility and individual decision-making." References to gender inequality are sprinkled throughout the consideration of sexuality, addiction prevention, and "study, work, and personal realization." 84

The program in civic and ethical formation ends with an ambitious final project meant to foster "responsibility, collective decision-making, and partici-

79. Id. at 55 .

80. Id. at 79. Part of this section includes a reflection on the local institution of "Student Council" (Sociedad de Alumnos), in which virtually every secundaria student body elects officers and representatives. While this tradition had fallen into disuse in some schools, by 2001 the Federal Electoral Institute (IFE) was collaborating with the Ministry of Education to revive and strengthen student elections in secundarias.

81. Id.

82. Id. at 85 .

83. Id. at 89 .

84. Id. at 97 . 
pation." Either in small groups, or as a whole class, students must "demonstrate that they are capable of making change in some aspect of their school or immediate environment. For this the youth must identify an improvable aspect of one of the broad fields that they've studied throughout the course: education, work, health, environment, and free time." 85

Through this project, students should learn how to arrive at decisions through consensus, how to conduct an empirical investigation and divide the work fairly amongst themselves, and how to present the results of an investigation to authorities and peers in order to effect positive change. The program description ends with a final observation of the anticipated "formative" benefits of this group project:

[This project will serve], above all, for the students to evaluate themselves, so that they can see in their practice how much the three years of being in the course has benefited them; [it is assumed that] upon completing the elaboration of their project the students will discover that they're capable of cooperating, joining a team, finding a problem and proposing viable solutions, coming to an agreement, respecting one another, and researching.... (translated by author) ${ }^{86}$

Clearly, the Mexican FCE program places primary emphasis on the enactment and embodiment of democratic values in everyday classroom practice. A constructivist and dialogical pedagogy postulates that through classroom process and explicit content, students will practice and learn democratic habits of participation, tolerance, dialogue, and cooperation. It is not surprising, given Mexico's history, that the values and dispositions of democracy include a strong emphasis on group work, solidarity, and the collective good. This is one of the key aspects of Mexican education for democratic citizenship that would seem to distinguish it from those strictly liberal models sponsored by the countries of the North, which tend to place higher emphasis on deliberation and the rights of possessive individualism. It might be said that, historically, Mexico's strong collective traditions and identities have served authoritarianism well, and that a democratic education must now balance the forces of collectivism with a focus

85. Id. at 104 .

86. Id. at 103-04. 
on individual rights and conscience. Yet in the articulation of this balance, the FCE still clearly highlights the importance of collective life and responsibilities. Individual conscience is no longer prescribed, but must be developed intersubjectively nonetheless. The student-citizen is the subject of a political imaginary in which personal reflexivity, respectful dialogue, and collective responsibility are paramount. Moreover, an analysis of the major themes and goals of the FCE program shows the authors attempting to address the concerns about values expressed in each of the societal discourses I have identified, yet still anchoring it most strongly in what I call the discourse of the "critical citizen." Thus, the FCE bears the imprint of the FCE authors' and sponsors' personal and ideological trajectories as members of the left-leaning opposition oriented to a democratic revolution within; of the authors' international experiences and familiarity with international materials; and of the authors' intention to be as inclusive as possible of societal concerns.

\section{Another Vision of Citizenship: Education for a Culture of Lawfulness}

The year 2000 was a watershed year in Mexican political history, one big step toward the fulfillment of democratic promise. In July of that year, long-standing single-party rule was effectively ended in Mexico with the election of the opposition candidate, Vicente Fox, and with the achievement of an opposition-majority in the bicameral Congress. ${ }^{87}$ Fox's party, Partido de Acción Nacional (PAN), has since made inroads into all major ministries, and he has made significant new appointments within the education ministry. While most Mexicans hailed these new developments as important steps on the road to full democracy, many worried that the rightist PAN, historically allied with the Catholic Church, would use its power to erode the strong separation of church and state that has characterized public education since the Revolution. The FCE program, because it centrally addresses questions of ethics, morality, and citizenship, was feared to be a beachhead through which the PAN might seek to introduce religion back into the schools. Even though the program had been created during a PRI administration, and explicitly eschewed sectarian dogma, its built-in flexibility was thought to create an opening for states and municipalities to invite religious influence.

87. See Julia Preston \& Sam Dillon, Opening Mexico (2004). 
Time does not appear to have borne out such fears, but the new PANappointed administration of the SEP has moved to make some important changes. Interestingly, unlike Limón, the new Secretary of Education has had little involvement in the process of ongoing civic education reform; rather, and perhaps more appropriately, it is once again the Subsecretary for Basic Education, now Lorenzo Gómez-Morín Fuentes, driving the process. Gómez-Morín is the grandson of one of the most beloved founders of the PAN, who was a leader of its so-called democratic wing. Having served as Secretary of Education in the populous and politically important state of Baja California Norte, he arrived in Mexico City to head up what is by far the largest and most significant division within the SEP. Hoping to expand the impact of civic education and "articulate" its components across different educational levels, he initiated a comprehensive set of reforms aimed at building an integral process of "citizenship formation" (formación ciudadana). As part of this campaign, Gómez-Morín commissioned the development of curricula in FCE for the fifth and sixth grades of primary school, as well as the first year or two of high school, or $e d u$ cación media superior. In 2001, he sponsored an unprecedented agreement for collaborative work between the Ministry of Education, the Ministry of the Interior (Gobernación), and the Federal Electoral Institute (IFE). These three agencies all have some aspect of citizenship education included among their various responsibilities, yet never before had they worked together in any systematic way. Finally, at the secundaria level, Gómez-Morín brought to the SEP a pet program for citizenship education that he had piloted in Baja California. This program, originally called "Culture of Lawfulness," was adapted to the Mexican context, where it has come to be called "Citizenship Formation, Towards a Culture of Lawfulness" (Formación Ciudadana, Hacia una Cultura de la Legalidad). ${ }^{88}$ The FCE program, meanwhile, had been in operation for less than two years.

The original version of education for a culture of lawfulness, or CL, is a project of the Washington, D.C.-based National Strategy Information Center (NSIC), a conservative think tank created in 1962 and directed since 1993 by Roy Godson, a professor of government at Georgetown University. ${ }^{89}$ With a background in intelligence work, Godson is a specialist in transnational security,

88. Secretaría de Educación Pública, at http:/sep.gob.mx (last visited Jan. 26, 2005).

89. See National Strategy Information Center, at www.strategycenter.org/index.htm (last visited Jan. 26, 2005). 
organized crime, and anticorruption programs. ${ }^{90} \mathrm{He}$ developed the CL framework primarily through his collaborative work in Sicily, Italy, where he played a major role in combating the mafia and helping create what has come to be called the "Sicilian Renaissance." ${ }^{91}$ Later, he refined his ideas about the program through further anticrime work in Hong Kong. ${ }^{92}$

In $A$ Guide to Developing a Culture of Lawfulness, Godson lays out some of the key principles and assumptions that guide his work. The concept of culture is central. According to Godson, regulatory and law enforcement approaches to crime prevention alone will not work. Rather, "[w]hat is needed is a complementary strategy that amounts to a fundamental shift in values. The regulatory approach needs to be accompanied by society or culture sympathetic to the rule of law." ${ }^{93}$ With enforcement and regulation as the "first wheel," a CL constitutes the "second wheel" of a two-wheeled cart. ${ }^{94}$ Godson continues by claiming that the shift in values constituting a CL can be accomplished in a relatively short timeframe, one generation:

The methods, techniques, and processes that will be delineated here are drawn largely from the recent experiences of two successful and ongoing endeavors. There was a significant change in the culture in such diverse regions and economies as Hong Kong and Sicily between the late 1970s and the late 1990s. These examples demonstrate that it is possible to shift a culture and bolster the rule of law even in areas where crime, corruption, and poverty have been prevalent for decades. Some of the techniques described here are also being used in efforts now under way on both sides of the MexicanU.S. border, as well as in such diverse areas as Botswana and the Republic of Georgia. Of course, the effective practices used and the experience gained in one society are not always applicable to others. But the key principles_elements that have been effective in one or

90. See National Strategy Information Center, Staff, at http://www.strategycenter.org/staff.htm (last visited Jan. 25, 2005).

91. Roy Godson, A Guide to Developing a Culture of Lawfulness (Dec. 14, 2000) (paper presented at the Symposium on the Role of Civil Society in Countering Organized Crime: Global Implications of the Palermo, Sicily Renaissance), available at www.unodc.org/palermo/godson.doc.

92. See id. at 6.

93. Id. at 2.

94. Id. at 2,5 . 
more cases and may be a useful guide that can be adapted to other situations-illustrate that cultural change, while difficult, can be brought about and sometimes in a relatively short time. ${ }^{95}$

According to Godson, then, the principles for developing a CL can, with certain adaptations, be usefully borrowed across societies. He is proposing a globally relevant scheme for crime prevention.

It is also important to note that both the discourse on citizenship and the discourse on democracy are muted in Godson's work. The relation between the "rule of law" and democracy is left largely implicit; sometimes, his writing in the Guide even suggests that the rule of law trumps democracy:

A culture of lawfulness means that the dominant or mainstream culture, ethos, and thought in a society are sympathetic to the rule of law. In a society governed by the rule of law, people have the ability to participate in the making and implementation of laws that bind all the people and institutions in society, including the government itself. It is not the same as rule by law in which the rulers-even if democratically elected - impose the law on others in society. Under the rule of law, everyone ... is to be treated uniformly. The ruler as well as the ruled is accountable to the rule of law. As U.N. Under Secretary-General, Pino Arlacchi has pointed out, it is the rule of law, not majority-based democracy, that protects all members of society, including the weaker elements, and even the foreigners in their midst. ${ }^{96}$

Nevertheless, Godson's program has in fact been tied to efforts at creating greater democratic "governability" in many "transition" regimes, such as those he mentions. ${ }^{97}$ In the case of Mexico, of course, Godson's program has been appropriated as part of a broader effort to "form citizens" for an emerging democratic society. The Mexican project, then, links citizenship to a CL. In the political imagery of the current SEP administration, a good democratic citizen is one who knows the law, obeys it, and helps others to obey it as well.

95. Id. at $2-3$.

96. Id. at 3 (emphasis in original) (internal citation omitted).

97. Id. 
In Godson's scheme to create a culture of lawfulness, three components are essential: school-based civic education, "centers of moral authority," and "media and popular culture." ${ }^{98}$ Godson makes compelling arguments about why each of these components is indispensable to the broad, "synergistic" education necessary for creating a new culture. "Centers of moral authority" refers to individuals and institutions, often religious in nature, that command moral respect in a society. ${ }^{99} \mathrm{He}$ gives the prominent example of Catholic church influence in combating Sicilian organized crime. ${ }^{100}$ The mass media and popular culture refers to the possible positive influence of news reporting against corruption and in favor of transparency, as well as the positive or negative influence that can be exercised by popular musicians, actors, artists, and others whose work is conveyed through the mass media. ${ }^{101}$ Most importantly for our purposes here, Godson highlights the role of school-based education. He says, "[s]chools are among the most important, widespread, and strategic civic education organizations[,]" and he specifically mentions the "early secondary" years as the best time "to reach children before they become involved in serious criminality and come to take it for granted that they live in a culture of corruption." 102

Out of this focus on education, Godson and his staff at the NSIC helped create specific curriculum materials for school instruction, which was part of the Culture of Lawfulness project. Godson collaborated with local educational authorities to implement this program in Sicily and elsewhere. ${ }^{103}$ As part of an effort to battle drug-related crime and corruption in the large border cities of Tijuana and Mexicali, in the late 1990s he was invited by then-Secretary of Education, Lorenzo Gómez-Morín, to pilot the program in Baja California. Collaborating with local curriculum specialists, a thirty-six-lesson course, organized into three separate units, was designed for students in their third year (ninth grade) of secundaria:

- Values, Self-Esteem, and a Culture of Lawfulness,

- Organized Crime and Corruption, and

\footnotetext{
98. See id. at $5-9$.

99. See id. at 7-9.

100. See id. at 7.

101. See id. at 9.

102. Id. at 6.

103. See Jane Scheider, Educating against the Mafia-A Report from Sicily, 3 CIVNET's J. FOR CIv. Soc'y 3 (1999) (attempting to evaluate some of the effects of this program in Sicily).
} 
- Furthering the Rule of Law, Resistance Techniques, and What Students Can Do. ${ }^{104}$

Among the more prominent curriculum materials were a Spanish translation of William Golding's classic novel, Lord of the Flies, which tells the story of how several shipwrecked boys succumb to their savage instincts and follow the most ruthless leader, and the 1990s movie Goodfellas, which portrays the cruelty of mafia activity. Each of these materials appears to serve as the basis for dialogue and reflection about how to avoid the temptations of illegal power. The school program, moreover, curiously appears to combine a more dialogical pedagogy, like the FCE, with heavy-handed moralizing. On the one hand, students are encouraged to critically discern corruption and other instances of the abuse of public power. They are invited to reflect and to question, and, as Schneider observed of ECL in Sicily, "[ $t$ ]he new pedagogy advocates a more open and direct pattern of communication between the generations." ${ }^{105}$ On the other hand, students are also taught clear rights and wrongs as stipulated by existing law, and they are encouraged to assume an obedient stance vis-à-vis the law. The course is much more prescriptive than the FCE, and much more academic as well. Demonstrating thorough knowledge of laws and constitutional principles is deemed absolutely prerequisite to the formation of proper attitudes and behavior. ${ }^{106}$

Judging the program a rousing success, ${ }^{107}$ Subsecretary Gómez-Morín arrived on the national scene in 2001, eager to expand it to other states. In Baja California, in the same year, the program expanded to cover approximately 20,000 students. ${ }^{108}$ Meanwhile, other states were learning of the innovation in Baja, and soon the program was being piloted in secundarias in four other Mexican states (mostly border states or states with histories of strong drug-trafficking), as well

104. Roy Godson \& Dennis Jay Kenney, Fostering a Culture of Lawfulness on the Mexico-U.S. Border: Evaluation of a Pilot School-Based Program, in Transnational Crime and Public Security: Challenges to Mexico and the United States 419 (John Bailey \& Jorge Chabat eds., 2001).

105. Scheider, supra note 103, at 13.

106. Godson \& Kenney, supra note 104.

107. Using a survey instrument and focus groups, the NSIC itself has conducted an evaluation of the project in Baja California, and has claimed significant improvement in "knowledge and attitudes" related to crime prevention. See Godson \& Kenney, supra note 104, at 454 . To my knowledge, no independent evaluation has been conducted.

108. Baja's Education/Cultural Initiative to Foster the Rule of LaW (Spring 2003) (on file with author). 
as two of the "delegations" within the federal district of Mexico City. ${ }^{109}$ By 2004, some 522 schools, 869 teachers, and 88,000 students were involved with the program, and it was projected to expand on a pilot basis to yet five more states. ${ }^{110}$ The ECL program has been slotted for the time being as a three-hour "elective" course determined by the individual states for the final year of secundaria study. It is meant to supplement the eight hours of FCE studied over the course of all three years of secundaria. Yet, with the forthcoming national "integral reform" of the secundaria soon to be implemented, it remains unclear whether and how ECL will survive. Since the reform is being driven by the current SEP administration, it is likely that ECL will come to form a significant part of a revamped FCE, whose eight hours a week will now be concentrated in the third and final year of secundaria. Moreover, in an apparent effort to expand beyond schoolbased education, the SEP has entered into partnership with the IFE and the Facultad Latinoamericana de Ciencias Sociales (FLACSO) to offer special courses in the Culture of Lawfulness to public officials and bureaucrats. ${ }^{111}$

What are we to make of the growing popularity of the CL program as part of a broad-based effort to "form citizens" for a democratic culture? Clearly, the success of the program is due primarily to the personal initiative and sponsorship of Gómez-Morín. Along with his chief advisor, Gómez-Morín believes strongly in the benefits of CL, and he uses his considerable resources and charisma to promote it. He also claims that the program has generated its own positive publicity, such that state educational authorities have actively sought the program out. Moreover, part of the appeal of CL, like the FCE, is that it allows states to customize the curriculum. The original curriculum, of course, was heavily influenced by developments in Sicily and Hong Kong, yet it too was a collaborative product between the NSIC and local experts in Baja Californiaalready one kind of "local appropriation." Now each state develops its own teachers' guide and curriculum materials for the course. However, one can be sure that the governing framework and ideology remain the same. The CL program appears to retain certain core meanings, relatively impermeable to local resignification, as it flows around the world. Among these core meanings is the

109. Id.

110. See Secretaría de Educación Pública, supra note 88. The national education plan for 2001-06 specifically mentions the goal of implementing the ECL program in $50 \%$ of all Mexican secundariasmost of them urban - by the end of the administrative period.

111. See Presenta México a Comunidad Educativa Internacional Avances en Cultura de la Legalidad en el Aula, at http://www.sep.gob.mx/wb2/sep/sep_Bol3681 103 (last visited Jan. 21, 2005). 
postulate that to be a "good citizen" is to fight crime, and to fight crime one must know and appreciate the law, thereby contributing to a "culture of lawfulness." To be a good citizen is also to obey the state rather than one's possible clientelistic obligations outside the law. The current SEP administration has appropriated this more limited vision of learning into an ambitious and far-reaching program for democratic citizenship, but the results of this hybrid configuration are uncertain. Clearly, the pedagogical premises and conceptions of democracy of the FCE and the ECL differ in significant ways.

If we look at the implementation of ECL as we did the FCE, then we must raise the question of how and why it has developed a certain way. Beyond the personal influence of the Subsecretary and the perceived benefits of the program, how does ECL respond to the societal discourses and concerns that I have identified? In contrast to the FCE, where the model of the "critical citizen" is prominent, ECL is more fundamentally rooted in societal discourses on "lost values" and "accountability." On the one hand, the program suggests a golden age, when citizens firmly valued the law, before the corrosive influence of extralegal actors, such as narcotraficantes. Now such values have been eroded, if not lost. ECL proposes to recover these values through a blend of moralizing, cautionary tales, and exhortation. On the other hand, the program is anchored by a strong respect for formal and procedural law, and the kind of transparency or accountability that ideally accompanies such law. In a country like Mexico, struggling with a legacy of corruption and the public cynicism that such corruption engenders, such a focus resonates strongly. It is in this respect, too, that the program attempts to incorporate elements of the discourse on the "critical citizen." Although the acknowledgement of this discourse is subdued, one can see how the secundaria student is being urged to adopt a critical stance toward criminals and corrupt politicians, and to resist being seduced by their temptations. This invites some questioning of authority, even of "democratically" elected leaders.

\section{Conclusion}

I have examined in this paper two recent programs for democratic citizenship education in Mexico. In both cases, I viewed the actions and initiatives of the federal education ministry as one instance of the local appropriation of global cultural flows. In the case of the FCE program, what gets appropriated are a variety of globally circulating discourses and conceptions of education for democratic citizenship. A heterogeneous collection of writings, programs, and cur- 
ricula on democratic citizenship education are reviewed by a specially assembled team. This team then appropriates and configures these heterogeneous elements into a final product - a curriculum - and a set of guidelines for implementing the product-a policy. The complex process of curriculum and policy formation is influenced by the team's personal biographies, the impact of societal discourses and movements on their political radar, and the advice and input of invited collaborators. In the case of the ECL course, what gets appropriated is a program and a curriculum outline that is already strongly formulated from outside the ministry. While the Subsecretary of Basic Education initially oversaw the development of a curriculum in Baja California, there is little evidence that this curriculum differs substantially from what one might find in Sicily or Hong Kong. The language, the history, and the cultural references vary, but the message is the same. Thus, the SEP effectively appropriates and implements a globalizing product with its embedded legalistic assumptions of democracy and citizenship.

There are several implications of this study for the understanding of cultural globalization as well as an emerging anthropology of democratic forms. ${ }^{112}$ We see in the Mexican case how globally circulating conceptions of democratic citizenship become uniquely appropriated by different administrations of the national education ministry in the development of policy and curriculum reform for democratic civic education. Most of these conceptions of citizenship originate in the liberal democracies of the North, but some are shared laterally through Latin American networks, some are inspired by Japan, and others, like ECL, even bear the imprint of moral education in Hong Kong. The form that such appropriation takes and the degree to which globalizing concepts and programs are resignified or "creolized," 113 depend on a number of factors, including: a) the nature of the interaction between national and global actors in a complex social field of programming and grant-making for "education for democracy"; b) the institutional dynamics and social networks of the state; c) the means by which national social movements and societal discourses enter into policy decisions; d) the degree of coherence and completeness of the globally circulating concepts or programs; and e) the interpersonal and institutional dynamics of national education ministries as the primary authorized policymaking bodies in the last instance.

112. See Julia Paley, Toward an Anthropology of Democracy, 31 Ann. Rev. of Anthropology 469 (2002).

113. See Ulf Hannerz, Transnational Connections: Culture, People, Places 65-66 (1996). 
Democracy, democratization, and democratic citizenship are thus multivalent and culturally situated concepts bound up with local identities and practices. Hegemonic forms of these concepts may indeed accompany flows of global capital to "newly democratizing" regions of the world, but such forms often (if not necessarily) become uniquely adapted and inflected by local bureaucratic and institutional cultures. The state continues to be a dynamic actor in the arena of democratization, but not simply as the purveyor of some "institutional isomorphism." 114 In this case, schooling is obviously one important dimension of state action in democratization, and the Ministry of Education is one key agency of the Mexican state. Through this Ministry, the state initiates movement toward creating a more democratic political culture, both as a response to societal discourses and, no doubt, external pressures. The Ministry then engages, in varying ways, with the many global organizations and fields that are involved in defining and educating for democratic citizenship. But in a broader mapping of the national social field, other state and civil society institutions have also taken as their charge the creation of "democratic citizens." This is plainly the case for the IFE and the Secretaria de Gobernación in Mexico, but it is no less true of sectors of the mass media, nongovernmental organizations, youth clubs, and so forth.

One of the challenges in the analysis of a program like FCE is to balance structural influences with the highly personalized processes through which the program concretely takes shape. Clearly, the existence of strong societal discourses on the need for values education in public schools created a political environment where a program like FCE would be possible, if not desirable. Clearly, too, external influences and examples, ranging from the United Nations' and the Organization of American States' declarations on human rights and democracy, ${ }^{115}$ to the varying "experiments" in democratic education around the globe, ${ }^{116}$ played a role in defining the possibilities of the moment. Yet, without the decisive and skillful actions of the Secretary and his wife, and without the support of a president willing to take political risk, such influences might not ever have found their way into educational reform. In a piece called Researching Inside the State, British sociologist of education Stephen Ball cautions against playing up individual actors too much in the analysis:

114. Thomas ET AL., supra note 10.

115. See generally Organization of American States, at http://www.oas.org (last visited Jan. 27, 2005).

116. See Democratizing Education, supra note 4; Diversity and Citizenship Education: Global Perspectives, supra note 4. 
[T] he problem always remains that by focusing on the figures which move across the policy landscape we may neglect the geomorphology of the landscape itself and changes in its terrain and substructure. On the other hand, a preoccupation with dominant modes of political rationality and global economic forces may lead to a misleading neglect of transformative activities and the possibility of surprise. It is the interplay between figure and landscape that is important theoretically and empirically. ${ }^{117}$

In the case of the original FCE program, I submit, we may be seeing one instance of "transformative activities" pursued within one sector of a key state ministry. At a time when neoliberal rationalities prevailed in the Mexican state, and global economic forces conspired to limit the horizons of citizenship to consumerism, flexible labor, and the self-regulating subject, conditions persisted in the Mexican Ministry of Education to enable a much broader sense of citizenship education. Taking into account the balance of social forces and ideological positions within Mexico, the authors of the FCE program, nevertheless, pursued the actualization of a strongly dialogical and participatory kind of democratic citizenship. They were able to make a highly considered, purposeful appropriation of global cultural flows to craft a program that could respond to the particularities of the Mexican situation. It is less clear, at this time, whether and how the ECL program similarly responds to Mexican particularities or similarly challenges the neoliberal premises of prevailing economic policy.

117. Stephen J. Ball, Researching Inside the State: Issues in the Interpretation of Elite Interviews, in Researching Education Policy: Ethical and Methodological Issues 107, 118 (David Halpin \& Barry Troyna eds., 1994). 